\title{
Effects of projected climate change on the distribution of Mantis religiosa suggest expansion followed by contraction
}

\author{
Johanna Steger ${ }^{1}$, Alexandra Schneider ${ }^{1}$, Roland Brandl ${ }^{1}$, and Stefan Hotes ${ }^{2}$ \\ ${ }^{1}$ Animal Ecology, Department of Ecology, Faculty of Biology, Philipps-Universität Marburg, \\ Karl-von-Frisch Strasse 8, 35032 Marburg, Germany \\ ${ }^{2}$ Faculty of Science and Engineering, Applied Landscape Ecology, Chuo University, 1-13-27 Kasuga, \\ Bunkyo-ku, Tokyo 112-8551, Japan
}

Correspondence: Johanna Steger (johanna.steger@biologie.uni-marburg.de)

Received: 6 May 2020 - Revised: 9 July 2020 - Accepted: 21 July 2020 - Published: 8 September 2020

\begin{abstract}
Climate change influences the global and regional distribution of many species. For thermophilic insects, range expansions towards the north and to higher elevations are expected in the course of climatic warming across the Northern Hemisphere. The distribution of the European mantis (Mantis religiosa) has recently expanded from Mediterranean regions in France to Hesse in central Germany. This is interpreted as a response to rising mean temperatures, and further northward expansion is expected to occur with increasing climate warming. In this study, potential changes in the regional distribution across Hesse were modeled for Mantis religiosa using the present distribution and climate across Europe as the baseline. We estimated potential changes in the regional distribution for two time periods until 2080 based on two climate change scenarios. The results showed that the current range of M. religiosa in Hesse is smaller than expected based on its climatic niche, i.e., the distribution is not in equilibrium with the present climate. With climate warming the model predicts an expansion of the potential distribution for the period 2041-2060. For the period 2061-2080, our model predicts, however, a range contraction in spite of continued warming. This unexpected result warrants further investigation in order to elucidate whether the ongoing climate change may have negative consequences for thermophilic species such as $M$. religiosa.
\end{abstract}

\section{Introduction}

Increasing greenhouse gas emissions have led to changes in the mean and seasonal variation of the air temperature (Hughes, 2000; Pecl et al., 2017; Hübener and Schönwiese, 2018). Temperatures are generally rising, and the warming has been shown to influence a large number of species, both negatively (Thomas et al., 2004; Descimon et al., 2005; Bässler et al., 2010; Jantz et al., 2015) and positively (Bale et al., 2002; Musolin, 2007). Insects, which are the largest taxonomic group of animals (Deutsch et al., 2008), are susceptible to climate change because they are ectothermic and thus are particularly sensitive to changes in air temperature (Beck, 1983). However, insects are also able to adapt rapidly to changes in their environment. Physiological adaptations allow insects to respond to an increase in temperature by extending their flight periods and by shifting events within their life cycles (Robinet and Roques, 2010). Further ecological responses include higher reproductive rates due to increasing the number of generations within a year (Menéndez, 2007). For some species, changing distribution ranges have been linked to changes in gene expression that confer physiological tolerance, such as cold resistance (Strachan et al., 2011; Telonis-Scott et al., 2012). For thermophilic insects in a warming climate, these responses may act in concert to allow an expansion of their distributional range northwards (Hickling et al., 2006; Menéndez, 2007; Robinet and Roques, 2010).

The European mantis Mantis religiosa prefers warm, sunny and dry habitats (Berg et al., 2011). With global 
warming, climatic conditions in central Europe have become warmer and drier (Bartholy et al., 2012), allowing $M$. religiosa to expand the northern border of its range from Mediterranean regions to southern and central Germany (Liana, 2007; Walther et al., 2009; Linn and Griebeler, 2016). M. religiosa is thought to have colonized Germany via two distinct routes: the central lineage has spread from the Czech Republic via Poland to the federal state of Brandenburg (Landeck et al., 2013; Zielinski et al., 2018), whereas the western lineage originated from eastern France and used the Burgundy Gate and/or the Moselle Valley (Berg, 2011) to reach central Europe. The two lineages show genetic differences (Linn and Griebeler, 2015). These routes have been used by many species during recolonization of central Europe after the last ice age; some of them also include distinct genetic lineages (e.g., the grasshopper Chorthippus parallelus, the two hedgehogs Erinaceus europaeus and E. concolor, and the European oak species; Hewitt, 1999; Aspöck, 2008). Stable populations of the western lineage of the European mantis in the German federal states of Rhineland-Palatinate and Saarland were first found in the 1990s (Petrischak and Ulrich, 2012; Linn, 2016); they were also found in Baden-Württemberg with high abundances at the "Kaiserstuhl" in the Upper Rhine valley (Petrischak and Ulrich, 2012). In the southern part of the German state of Hesse, M. religiosa has had established populations since 2004. Because the species is considered to be relevant for conservation (HLNUG, 2017), monitoring and management activities were then initiated. Distribution models focusing on the regional scale that take into account the influence of climate factors on native species and alien species are important for nature conservation planning, which is in the area of competence of the federal states in Germany. Therefore, we focused on the federal state of Hesse and addressed two questions: first, is the present distribution of $M$. religiosa in equilibrium with current climatic conditions, i.e., has the species established populations in all suitable areas? This question follows from an analysis of historical records of the upper elevational border of insects in the Bavarian forest, where predictions based on climate warming fell short of the actual distribution (Bässler et al., 2013). The second question addressed the relative importance of different climate variables for changes in the distribution of M. religiosa in Hesse: is the mean annual temperature sufficient to predict the distribution of this ectothermic species, or do other aspects of climate play a key role?

\section{Material and methods}

\subsection{Species and environmental data}

Distribution data for $M$. religiosa are available from the Global Biodiversity Information Facility (GBIF.org, 2018) and from the database of the Hessian State Office of Conservation, Environment and Geology (HLNUG, Abteilung
Naturschutz, 2018). Both datasets only contain presence data. A total of 39 occurrences of the praying mantis were reported from Hesse. As climate change in Hesse is expected to create climatic conditions that are similar to those in other parts of the European range of M. religiosa, modeling was based on records from its entire distribution range in Europe, combining all the records from GBIF and from the database for Hesse.

An underlying assumption in distribution models is that the distribution of a species is in equilibrium with environmental conditions (Gallien et al., 2012). However, an equilibrium cannot be expected for an expanding species at its distributional border (Václavík and Meentemeyer, 2012). We assumed that this issue would not unduly affect the results of the study because most of the records came from the center of the distribution of the western lineage of mantis, where an equilibrium between the distribution and environmental conditions is likely.

After duplicate records were removed, the final dataset used in our study comprised 2799 occurrence points and contains the GBIF dataset and the reported locations in Hesse. To compare the environmental conditions at these points with the overall environmental conditions in Europe, 8000 background points were randomly generated (Phillips et al., 2004; Phillips and Dudík, 2008). The background points were distributed across the actual entire distribution area of Europe. Bioclimatic data were retrieved from the CHELSA database (http://chelsa-climate.org/, last access: 24 May 2019), which includes 19 bioclimatic variables (Table 1). The variables have a spatial resolution of $30 \mathrm{arcsec}$ (approx. $600 \mathrm{~m}$ ) and are based on monthly averages for temperature and precipitation over the period 1979-2013.

Both current climate data and projections until 2080 (2041-2060 and 2061-2080), each with four different emission scenarios (representative concentration pathways, RCPs) are available in the CHELSA database. The four scenarios are denoted as RCP 2.6, RCP 4.5, RCP 6.0 and RCP 8.5 , with the numerical values indicating the magnitude of the mean temperature increase expected by 2100 . The scenarios are driven by predicted levels of greenhouse gas emissions and are therefore related to environmental policies (IPCC, 2014). RCP 8.5 assumes a "business-as-usual" approach without particular interventions, leading to a fourfold increase in atmospheric $\mathrm{CO}_{2}$ concentrations from preindustrial values by 2100 . By contrast, the mitigation strategies assumed in RCP 2.6 would reduce global greenhouse gas emissions after a decade, with near-zero levels reached $\sim 60$ years from now. In this scenario, the increase in the global mean temperature since pre-industrial times is unlikely to exceed $2^{\circ} \mathrm{C}$ (IPCC, 2014). We used both RCP 2.6 and RCP 8.5 in our study. 
Table 1. Bioclimatic variables of the CHELSA database (http://chelsa-climate.org/, last access: 24 May 2019), the situation under current conditions, and the values for Hesse according to scenarios RCP 2.6 and RCP 8.5. Each value was calculated on the basis of 80204 grid cells for Hesse. One cell measures approx. $600 \mathrm{~m} \times 600 \mathrm{~m}$.

\begin{tabular}{|c|c|c|c|c|c|c|c|c|c|c|c|}
\hline \multirow[t]{3}{*}{ Variable } & \multirow[t]{3}{*}{ Name } & \multirow[t]{3}{*}{ Unit } & \multicolumn{9}{|c|}{ Situation in Hesse } \\
\hline & & & \multicolumn{3}{|c|}{ Actual } & \multicolumn{3}{|c|}{ Scenario RCP 2.6} & \multicolumn{3}{|c|}{ Scenario RCP 8.5} \\
\hline & & & Min & Max & Mean & Min & Max & Mean & Min & Max & Mean \\
\hline Annual mean temperature & bio01 & ${ }^{\circ} \mathrm{C}$ & 5.3 & 11 & 8.9 & 6.2 & 12 & 9.9 & 7.3 & 13 & 11 \\
\hline Mean diurnal range & bio02 & ${ }^{\circ} \mathrm{C}$ & 6.6 & 7.2 & 6.9 & 8.9 & 9.6 & 9.3 & 10.9 & 11.9 & 11.3 \\
\hline Isothermality (BIO2/BIO7) & bio03 & ${ }^{\circ} \mathrm{C}$ & 2.7 & 2.9 & 2.8 & 3.3 & 3.5 & 3.3 & 3.7 & 3.8 & 3.7 \\
\hline Temperature seasonality (standard deviation) & bio04 & ${ }^{\circ} \mathrm{C}$ & 5.8 & 6.6 & 6.3 & 6.1 & 7.0 & 6.6 & 6.3 & 7.3 & 6.8 \\
\hline Max temperature of warmest month & bio05 & ${ }^{\circ} \mathrm{C}$ & 18.3 & 24.8 & 22.3 & 20.2 & 27 & 24.2 & 22.7 & 29.5 & 26.9 \\
\hline Min temperature of coldest month & bio06 & ${ }^{\circ} \mathrm{C}$ & -6.1 & -0.4 & -2.2 & -7 & -1.4 & -3.2 & -7.3 & -1.6 & -3.4 \\
\hline Temperature annual range (BIO5-BIO6) & bio07 & ${ }^{\circ} \mathrm{C}$ & 23.1 & 25.8 & 24.5 & 25.8 & 29.2 & 27.5 & 28.5 & 31.9 & 30.3 \\
\hline Mean temperature of wettest quarter & bio08 & ${ }^{\circ} \mathrm{C}$ & -2.1 & 19.5 & 12.2 & -1.4 & 20.9 & 13.2 & -1.4 & 23 & 12.1 \\
\hline Mean temperature of driest quarter & bio09 & ${ }^{\circ} \mathrm{C}$ & -2.7 & 12.2 & 4.2 & -2.4 & 20.1 & 4.6 & -1.3 & 15.6 & 11.2 \\
\hline Mean temperature of warmest quarter & bio10 & ${ }^{\circ} \mathrm{C}$ & 13.8 & 20 & 17.6 & 15.2 & 21.5 & 19.1 & 16.7 & 23.2 & 20.7 \\
\hline Mean temperature of coldest quarter & bio11 & ${ }^{\circ} \mathrm{C}$ & -3 & 2.5 & 0.7 & -2.4 & 3.2 & 1.3 & 0 & 3.6 & 1.7 \\
\hline Annual precipitation & bio12 & $\mathrm{mm}$ & 466 & 1485 & 793 & 450 & 1430 & 768 & 463 & 1497 & 794 \\
\hline Precipitation of wettest month & bio13 & $\mathrm{mm}$ & 48 & 163 & 84 & 50 & 146 & 84 & 47 & 166 & 82 \\
\hline Precipitation of driest month & bio14 & $\mathrm{mm}$ & 29 & 97 & 52 & 28 & 89 & 48 & 32 & 85 & 51 \\
\hline Precipitation seasonality (coefficient of variation) & bio15 & $\mathrm{mm}$ & 8 & 24 & 14 & 9 & 24 & 15 & 6 & 23 & 13 \\
\hline Precipitation of wettest quarter & bio16 & $\mathrm{mm}$ & 144 & 465 & 242 & 134 & 428 & 231 & 137 & 490 & 235 \\
\hline Precipitation of driest quarter & bio17 & $\mathrm{mm}$ & 91 & 303 & 164 & 87 & 283 & 155 & 100 & 268 & 160 \\
\hline Precipitation of warmest quarter & bio18 & $\mathrm{mm}$ & 139 & 367 & 218 & 123 & 332 & 196 & 137 & 371 & 216 \\
\hline Precipitation of coldest quarter & bio19 & $\mathrm{mm}$ & 97 & 371 & 181 & 87 & 350 & 164 & 100 & 398 & 190 \\
\hline
\end{tabular}

\subsection{Statistical analyses and mapping}

To predict the potential current and future distributions of $M$. religiosa, we used the maximum entropy approach implemented in Maxent. This method is available in the dismo package for $\mathrm{R}$ (version 3.5.3). Maxent is a popular method for species distribution modeling and is able to work with presence-only data (Elith et al., 2011; Merow et al., 2013; Amici et al., 2015). To select the explanatory variables for the baseline model of the current distribution of M. religiosa, we applied the function MaxentVariableSelection (Jueterbock et al., 2016; Gottwald et al., 2017; Steger et al., 2020) with the following settings: (1) a contribution threshold for inclusion in the model of $2 \%$, a value that reflects the importance of environmental variables in limiting the distribution of the species; (2) a correlation threshold of 0.7 to exclude correlated predictor variables; and (3) the use of a beta multiplier from 0.5 to 3.0 to regulate the fitting of the projected distribution to the training data. All combinations of the different feature classes of Maxent (linear, quadratic, product, threshold and automatic feature selection) were included, and forward stepwise selection was carried out to obtain the best combination of variables. In total, 1815 models of 64 different feature class combinations were calculated. The area under the receiving operator curve (AUC) and the corrected Akaike information criterion (AICc) were used to evaluate the models and to select the most parsimonious one. The AUC value can be interpreted as the probability of a randomly selected occurrence point being rated higher than a randomly selected background point (Fieldling and Bell, 1997). The AICc takes the number of parameters into account and selects the model with the lowest number of predictive variables (Warren et al., 2014). The relative importance of each climate variable included in the model was evaluated using the Jackknife method implemented in the Maxent program (Phillips et al., 2006). The chosen output format was "logistic", which yields an indicator for the relative probability of occurrence, a value that is easy to interpret and visualize (Phillips et al., 2009; Merow et al., 2013). The distribution model obtained using the data on current climatic conditions was subsequently used to predict the potential future distribution under the two climate change scenarios (RCP 2.6, RCP 8.5) for the time periods 2041-2060 and 2061-2080, respectively. The baseline model used ca. 36 million grid cells representing all of Europe, whereas the projected future distribution was calculated using the 80240 grid cells of the German federal state of Hesse. For the predictions of the future distribution, the model of the current distribution was used, with the predicted climatic variables entered into the model for the two emission scenarios and the two time spans. The occurrence probability in each grid cell was displayed on a scale from 0 to 1 . The suitability of potential distribution areas was classified as described in Yang et al. (2013) with low $(<0.2)$, moderate (0.2-0.4), good (0.4-0.6) and high (>0.6) occurrence probability. The resulting distribution maps were edited in QGIS Desktop (version 3.4.2.). 


\section{Results}

The best model for the current climatic situation had an AUC of 0.87 . For this model, the variables with the highest predictive power selected using the jackknife method were bio04, bio05, bio11, bio15 and bio18 (Table 2). The variable with the largest contribution was temperature seasonality (bio04, $54 \%)$ and that with the lowest contribution was the seasonality of precipitation (bio15, $2 \%$ ).

The predicted current distribution range with a good occurrence probability exceeded the area with actual records of M. religiosa (Fig. 1). Only in the region around Frankfurt do records of species occurrences largely match the areas with good (0.4-0.6) and high (>0.6) predicted occurrence probabilities. Nevertheless, the high potential areas are exceeded, i.e., the species has already spread northwards into the good potential areas (Fig. 1). In the north of Hesse, almost no areas with good or high potential for the occurrence of the European mantis were detected. A large area with a good potential for the occurrence but without actual records was found around the city of Gießen. All of the low mountain ranges in Hesse (e.g., Vogelsberg, between Gießen and Fulda; Rhön, west of Fulda; and Taunus, northeast of Frankfurt) showed only low probabilities $(<0.2)$ for the occurrence of M. religiosa under the current climate.

Modeling the distribution of M. religiosa using RCP 2.6 (Fig. 2) yielded a spatial pattern of predicted occurrence probabilities until 2060 that was quite similar to the pattern predicted for the current climate. Overall, Hesse was divided into suitable southern areas and mostly unsuitable northern areas. Under scenario RCP 8.5, the area of good and moderate potential habitat was predicted to be larger than under RCP 2.6 between 2041 and 2060, and almost no lowpotential habitat remained (Fig. 2). According to both scenarios, the low mountain ranges of Taunus and Vogelsberg, as well as the Rhön, will not have suitable areas for $M$. religiosa in the future either. During the period 2061 to 2080, however, areas with good and high potential were predicted to decrease under the RCP 8.5 scenario (Fig. 2). Overall, only moderate changes in the distribution of M. religiosa in Hesse were predicted.

\section{Discussion}

Climate has been shown to influence the life history of many insect species (Menéndez, 2007). Insects are ectothermic and rapidly react to changes in their physical environment, especially to changes in temperature (Beck, 1983; Bale et al., 2002; Zeuss et al., 2017). Our baseline model identified temperature seasonality (bio04) as the most influential variable for the potential future distribution of M. religiosa in Hesse. It is defined as the standard deviation of the monthly temperature averages throughout the year (Xu et al., 2013; Grünig et al., 2017), and larger values indicate greater temperature differences between the months.



Figure 1. Map of the occurrences as collated by the database of the Hessian State Office for Nature Conservation, Environment and Geology and current potential areas of Mantis religiosa in Hesse, predicted using the Maxent method. The model is based on the distribution of the mantis across Europe with actual climatic conditions (see also Tables 1 and 2).

The response curve of our model showed that the occurrence probability of $M$. religiosa decreased abruptly between temperature seasonality values between 7 and 8 (Fig. 3), suggesting that this represents a critical value that limits the occurrence probability of $M$. religiosa. Therefore, a high variability between the monthly temperatures is not beneficial for the Mantis religiosa. The curve shows that the smaller the temperature seasonality is, the higher the occurrence probability will be.

The second most influential variable in our model was the mean temperature of the coldest quarter (bio11). Consistent with our initial observations, the probability of M. religiosa occurrence increased if the temperature during the coldest quarter rose (Fig. 3). Thus, not only warm summers but also warm winters are clearly beneficial to the mantis (Parent, 1976, as cited in Berg et al., 2011). Females of the European mantis deposit their eggs in up to three egg cases in autumn, with the eggs then undergoing a diapause in winter 
Table 2. Range and mean values of climatic variables included in the baseline model for Hesse as well as the range of values for these variables from locations with records of Mantis religiosa. Bio04 is temperature seasonality (standard deviation), bio05 is max temperature of warmest month $\left.\left({ }^{\circ} \mathrm{C}\right]\right)$, bio1 1 is mean temperature of the coldest quarter $\left({ }^{\circ} \mathrm{C}\right)$, bio 15 is precipitation seasonality (coefficient of variation), and bio18 is precipitation of the warmest quarter ( $\mathrm{mm}$ per quarter).

\begin{tabular}{lrrrrr}
\hline & Contribution [\%] & \multicolumn{2}{c}{$\begin{array}{c}\text { Range and mean of current } \\
\text { climatic data in Hesse }\end{array}$} & \multirow{2}{*}{$\begin{array}{c}\text { Conditions at locations with } \\
\text { records M. religiosa in Hesse }\end{array}$} \\
\cline { 2 - 4 } & & Min & Max & Mean & \\
\hline bio04 & 53.9 & 5.8 & 6.6 & 6.3 & $6.3-6.4$ \\
bio11 & 20.3 & -3 & 2.5 & 0.7 & $1.8-2.4$ \\
bio05 & 18.3 & 18.3 & 24.8 & 22.3 & $24.3-24.9$ \\
bio18 & 5.5 & 139 & 367 & 218 & $134-155$ \\
bio15 & 2 & 8 & 24 & 14 & $-3.6-5.6$ \\
\hline
\end{tabular}

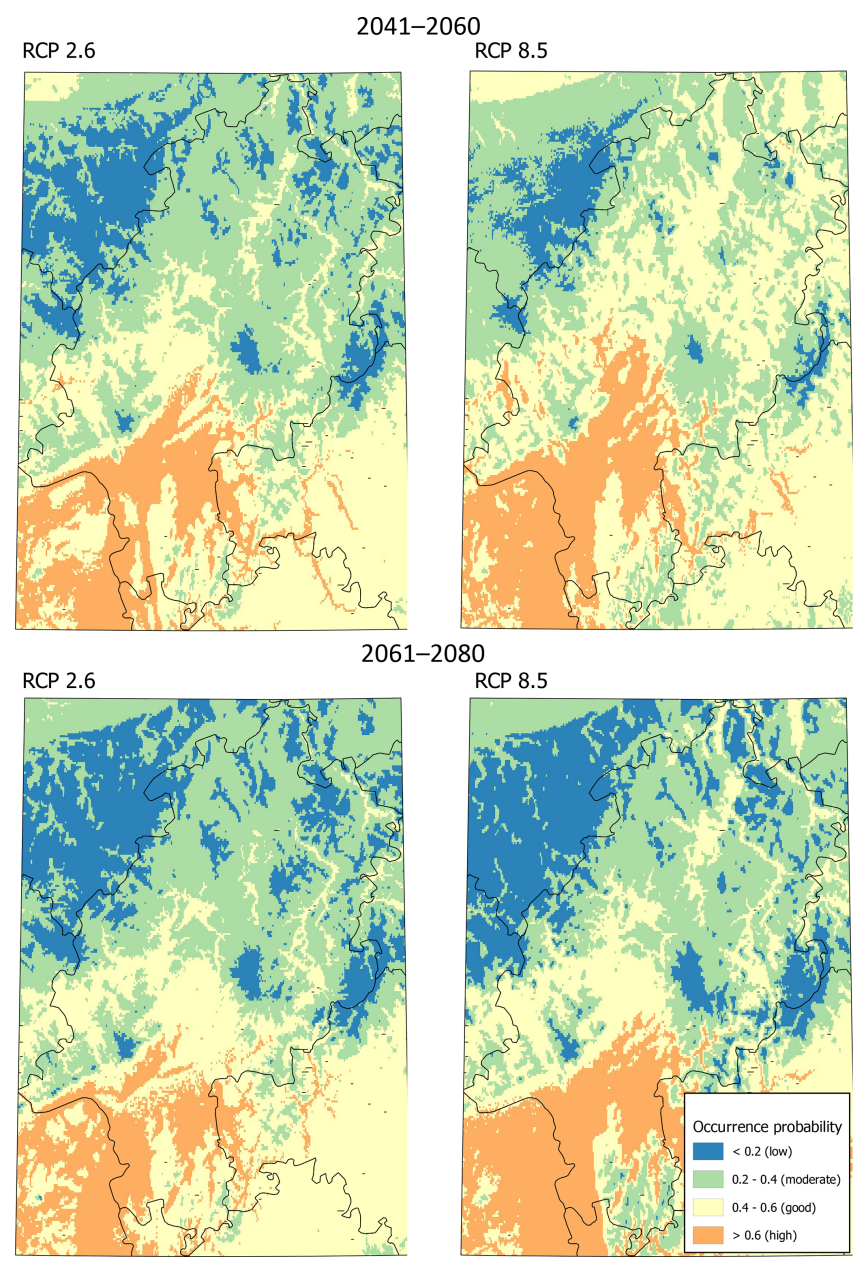

Figure 2. Maps of the potential distribution areas of M. religiosa in Hesse, Germany. The potential future distribution during two time periods was predicted using the identified variables under actual climate conditions and the scenarios RCP 2.6 and RCP 8.5.

(Berg et al., 2011). As the temperatures increases in spring, the eggs continue to develop and $\sim 125$ larvae per clutch hatch in May-June (Linn and Griebeler, 2016). The life cy- cle of the European mantis therefore depends on the winter temperatures and on an early temperature increase in spring. A longer vegetation period may lead to a growing population and thus to a larger number of dispersing individuals (Liana, 2007). This could be mediated by female mantises producing more than one egg case during longer summers (Harz, 1983). Favorable temperatures in spring are important for larval development (Linn, 2016). Cold springs with a lot of precipitation can delay ootheca hatching and sometimes even drive populations to extinction (Ehrmann, 2011). As the environment becomes warmer in response to climate change, new habitats with suitable conditions for the hatching and early development of $M$. religiosa may become increasingly available. Warm, dry conditions also could ensure a better food supply for this carnivorous insect, based on the assumption that climate change will have positive effects on its food resources, i.e., other insects (Berg et al., 2011; Ehrmann, 2011; Linn, 2016).

The predicted current distribution area of $M$. religiosa in Hesse was larger than the area from which occurrences have actually been reported, which suggests that the distribution of the European mantis may not have reached equilibrium with respect to climatic variables at this distributional border. The model predicting the current distribution was calculated using records from across Europe. These data roughly cover the range where the species has established populations for a longer time period and might have reached equilibrium with climatic conditions; thus, one can assume that our model predicted the area that would have been occupied by the insect if its distribution was at an equilibrium with the climate. The northern boundary of the potential range in Hesse was located in the area of the cities of Gießen and Marburg, whereas the current northernmost observations are located south of and around Frankfurt. Several reasons might explain why distribution lags behind climate. First, the large metropolitan region of Frankfurt and/or natural boundaries such as the Taunus, a low mountain range west of Frankfurt consisting of unsuitable areas, may have hindered the spread of $M$. religiosa. Second, intensive land use and habitat frag- 

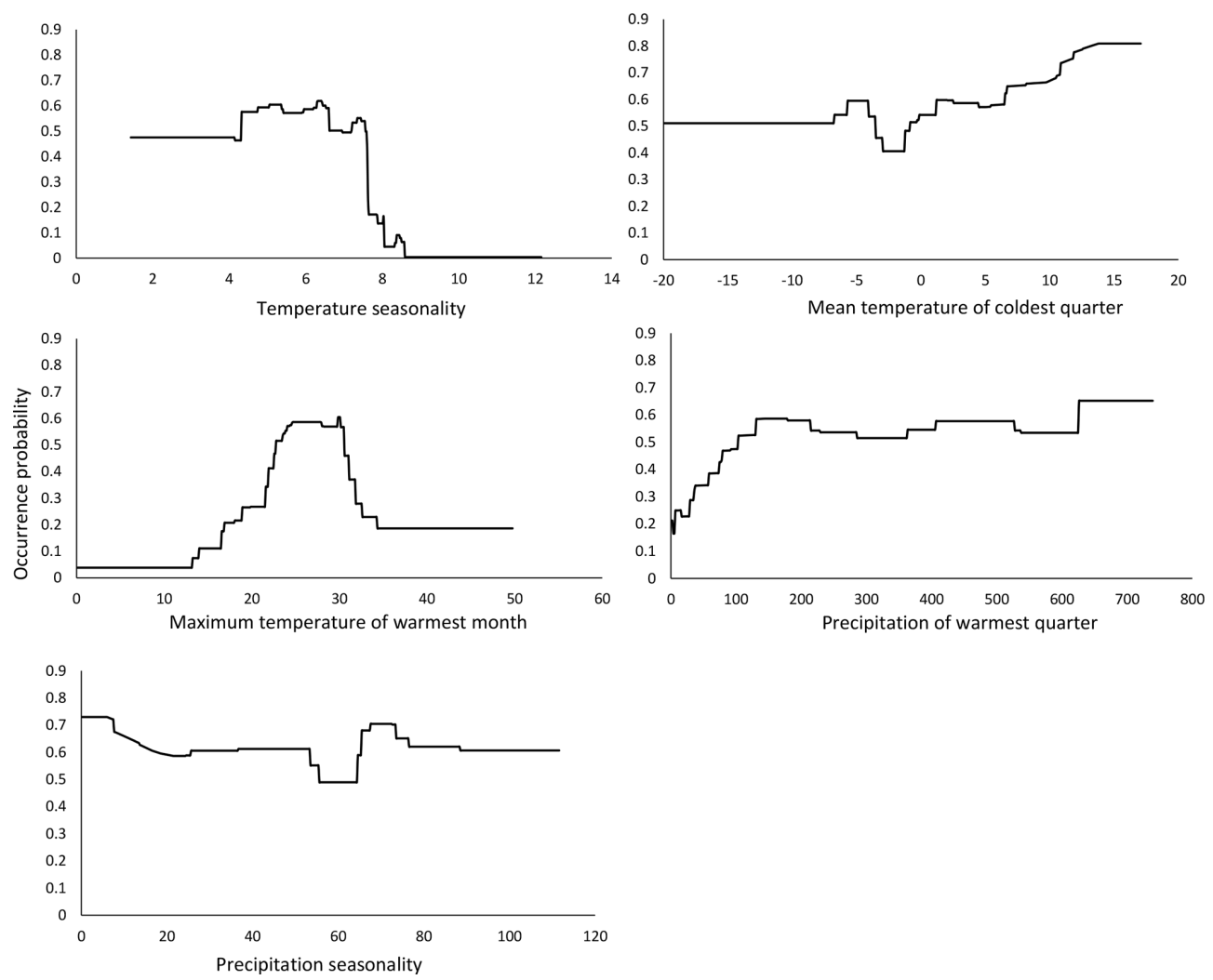

Figure 3. Response curves of the predictor variables of temperature seasonality, mean temperature of coldest quarter, max temperature of warmest month, precipitation of warmest quarter and precipitation seasonality, as functions of the occurrence probability in the model that predicts the actual potential distribution (Fig. 1).

mentation, together with the low dispersal ability of the European mantis, may have slowed expansion.

Prediction of the future distribution of $M$. religiosa must take unpredictable climatic events such as heat waves, extreme droughts with no precipitation or storm surges into account. The largest expansion of the distribution area might be expected in the case of climate change scenario RCP 8.5, a worst-case scenario of no greenhouse gas mitigation strategies, that would lead to the largest increase in temperature and a significant decrease in precipitation. While these environmental changes might be expected to be favorable for the European mantis, only a slight northward expansion of the distribution of M. religiosa was predicted to occur by 2041 . Why the benefit provided by the predicted climate warming does not translate into a larger expansion of the thermophilic $M$. religiosa is unclear.

In contrast to the increase in suitable areas predicted by RCP 8.5 until 2041, by 2080 the amount of suitable area was predicted to decrease to a range similar to that predicted by scenario RCP 2.6. Thus, while in the next 20 years species such as M. religiosa might profit from global warming, in the 20 years thereafter losses in areas of high potential might be expected. This observation might be explained due to the increase of diseases and pathogenes which profit from shorter and milder winters in the ongoing climate warming (Harvell et al., 2002). Under the scenario of RCP 2.6, according to which the rise in temperatures will be relatively small, the distribution area of M. religiosa until 2080 will not expand much compared with the current predicted area. However, regardless of future scenarios, an expansion of the range of $M$. religiosa to the predicted current area might be expected, although the speed of this expansion remains speculative. Nevertheless, our model shows that, at least on a regional scale, climate warming may lead to fluctuating distributional borders of thermophilic species despite a continued warming of the climate.

While generalist species of insects can readily establish themselves in new areas, changing conditions pose a challenge to the survival of specialists (Pampus, 2004). For $M$. religiosa, reproduction occurs under specific environmental conditions, and a spread is potentially limited by the insect's sedentary lifestyle. Nonetheless, $M$. religiosa has benefitted from the recent warming of temperatures in central Europe, expanding its range boundary to Hesse. A study by Linn and Griebeler (2016) showed that the distribution of M. religiosa is more strongly limited by the influence of environmental conditions on adults rather than on eggs, which especially during the maturation period could be spread passively by 
wind. Humans might also be a driver of dispersal processes, inadvertently transporting $M$. religiosa to regions conducive to its establishment. Either mechanism would allow the European mantis and other sedentary species to overcome large distances.

In summary, this study showed that species such as $M$. religiosa can be expected to benefit from a decreasing temperature seasonality during the next 20 years. The finding that continued climate warming as projected for the businessas-usual scenario of RCP 8.5 may not translate into further northward or upward shifts of the range boundary calls for further investigation of the causal links between climate variables and determinants of the distribution range of thermophilic insects.

Data availability. The occurrence data can be downloaded from https://doi.org/10.15468/dl.s0fpzo (GBIF.org, 2018) in their current form. The dataset from Hesse is not publicly accessible. Current climate data and the future projections of the respective climate change scenarios can be downloaded at http://chelsa-climate.org (Karger et al., 2017).

Author contributions. JS designed the modeling processes and developed the modeling code, and AS carried them out. JS prepared the manuscript with contributions from all co-authors.

Competing interests. The authors declare that they have no conflict of interest.

Review statement. This paper was edited by Daniel Montesinos and reviewed by two anonymous referees.

\section{References}

Amici, V., Eggers, B., Geri, F., and Battisti, C.: Habitat suitability and landscape structure: a maximum entropy approach in a mediterranean area, Landscape Res., 40, 208-225, 2015.

Aspöck, H.: Postglacial formation and fluctuations of the biodiversity of Central Europe in the light of climate change, Parasitol. Res., 103 Suppl. 1, S7-10, https://doi.org/10.1007/s00436-0081057-6, 2008

Bale, J. S., Masters, G. J., Hodkinson, I. D., Awmack, C., Bezemer, T. M., Brown, V. K., Butterfield, J., Buse, A., Coulson, J. C., Farrar, J., Good, J. E. G., Harrington, R., Hartley, S., Jones, T. H., Lindroth, R. L., Press, M. C., Symrnioudis, I., Watt, A. D., and Whittaker, J. B.: Herbivory in global climate change research: direct effects of rising temperature on insect herbivores, Glob. Change Biol., 8, 1-16, https://doi.org/10.1046/j.13652486.2002.00451.x, 2002.

Bartholy, J., Pongrácz, R., Nagy, J., Pieczka, I., and Hufnagel, L.: Regional climate change impacts on wild animals' living territory in Central Europe, Appl. Ecol. Environ. Res., 10, 107-120, 2012.
Bässler, C., Hothorn, T., Brandl, R., and Müller, J.: Insects overshoot the expected upslope shift caused by climate warming, PLoS ONE, 8, e65842, https://doi.org/10.1371/journal.pone.0065842, 2013.

Bässler, C., Müller, J., Hothorn, T., Kneib, T., Badeck, F., and Dziock, F.: Estimation of the extinction risk for high-montane species as a consequence of global warming and assessment of their suitability as cross-taxon indicators, Ecol. Indic., 10, 341352, https://doi.org/10.1016/j.ecolind.2009.06.014, 2010.

Beck, S. D.: Insect Thermoperiodism, Annu. Rev. Entomol., 28, 91-108, https://doi.org/10.1146/annurev.en.28.010183.000515, 1983.

Berg, M. K., Schwarz, C. J., and Mehl, J. E.: Die Gottesanbeterin: Mantis religiosa, 1. Aufl., Die neue Brehm-Bücherei, 656, Westarp Wissenschaften, Hohenwarsleben, 521 pp., 2011.

Descimon, H., Bachelard, P., Boitier, E., and Pierrat, V.: Decline and extinction of Parnassius apollo populations in France-continued, Studies on the Ecology and Conservation of Butterflies in Europe, 1, 114-115, 2005.

Deutsch, C. A., Tewksbury, J. J., Huey, R. B., Sheldon, K. S., Ghalambor, C. K., Haak, D. C., and Martin, P. R.: Impacts of climate warming on terrestrial ectotherms across latitude, P. Natl. Acad. Sci. USA, 105, 6668-6672, https://doi.org/10.1073/pnas.0709472105, 2008.

Ehrmann, R.: Mantis religiosa religiosa LINNÉ, 1758 in Deutschland und angrenzenden Ländern (Insecta: Mantodea), Articulata, 26, 135-146, 2011.

Elith, J., Phillips, S. J., Hastie, T., Dudík, M., Chee, Y. E., and Yates, C. J.: A statistical explanation of MaxEnt for ecologists, Divers. Distrib., 17, 43-57, https://doi.org/10.1111/j.14724642.2010.00725.x, 2011.

Fieldling, A. and Bell, J.: A review of methods for the assessment of prediction errors in conservation presence/absence models, Environ. Conserv., 24, 38-49, https://doi.org/10.1017/S0376892997000088, 1997.

Gallien, L., Douzet, R., Pratte, S., Zimmermann, N. E., and Thuiller, W.: Invasive species distribution models - how violating the equilibrium assumption can create new insights, Global Ecol. Biogeogr., 21, 1126-1136, https://doi.org/10.1111/j.14668238.2012.00768.x, 2012.

GBIF.org: GBIF Occurrence Download Mantis religiosa, https://doi.org/10.15468/dl.s0fpzo, 2018.

Gottwald, J., Appelhans, T., Adorf, F., Hillen, J., and Nauss, T.: High-Resolution MaxEnt Modelling of Habitat Suitability for Maternity Colonies of the Barbastelle Bat Barbastella barbastellus (Schreber, 1774) in RhinelandPalatinate, Germany, Acta Chiropterol., 19, 389-398, https://doi.org/10.3161/15081109ACC2017.19.2.015, 2017.

Grünig, M., Beerli, N., Ballesteros-Mejia, L., Kitching, I., and Beck, J.: How climatic variability is linked to the spatial distribution of range sizes: seasonality versus climate change velocity in sphingid moths, J. Biogeogr., 44, 2441-2450, https://doi.org/10.1111/jbi.13051, 2017.

Harvell, C. D., Mitchell, C. E., Ward, J. R., Altizer, S., Dobson, A. P., Ostfeld, R. S., and Samuel, M. D.: Climate warming and disease risks for terrestrial and marine biota, Science, 296, 2158 2162, https://doi.org/10.1126/science.1063699, 2002.

Harz, K.: Zum Paarungsverhalten von Mantis religiosa L., Articulata, 2, 25-26, 1983. 
Hewitt, G. M.: Post-glacial re-colonization of European biota, Biol. J. Linn. Soc., 68, 87-112, https://doi.org/10.1006/bij1.1999.0332, 1999.

Hickling, R., Roy, D., Hill, J. K., Fox, R., and Thomas, C. D.: The distributions of a wide range of taxonomic groups are expanding polewards, Glob. Change Biol., 12, 450-455, https://doi.org/10.1111/j.1365-2486.2006.01116.x, 2006.

HLNUG: Gottesanbeterinnen in Südhessen profitiert von der Klimaerwärmung, Gießen, 2017.

Hübener, H. and Schönwiese, C.-D. (Eds.): Beobachteter Klimawandel, Stand September 2018, Klimawandel in Hessen, Hessisches Landesamt für Naturschutz, Umwelt und Geologie, Fachzentrum Klimawandel Hessen, Wiesbaden, 23 Seiten, 2018.

Hughes, L.: Biological consequences of global warming: is the signal already apparent?, Trends Ecol. Evol., 15, 56-61, https://doi.org/10.1016/S0169-5347(99)01764-4, 2000.

IPCC: Climate change 2014: Synthesis report, Contribution of Working Groups I, II and III to the Fifth Assessment Report of the, Intergovernmental Panel on Climate Change, Geneva 2, Switzerland, 1 online resource, 151 pp., 2014.

Jantz, S. M., Barker, B., Brooks, T. M., Chini, L. P., Huang, Q., Moore, R. M., Noel, J., and Hurtt, G. C.: Future habitat loss and extinctions driven by land-use change in biodiversity hotspots under four scenarios of climate-change mitigation, Conserv. Biol., 29, 1122-1131, https://doi.org/10.1111/cobi.12549, 2015.

Jueterbock, A., Smolina, I., Coyer, J. A., and Hoarau, G.: The fate of the Arctic seaweed Fucus distichus under climate change: an ecological niche modeling approach, Ecol. Evol., 6, 1712-1724, https://doi.org/10.1002/ece3.2001, 2016.

Karger, D. N., Conrad, O., Böhner, J., Kawohl, T., Kreft, H., Soria-Auza, R. W., Zimmermann, N. E., Linder, H. P., and Kessler, M.: Climatologies at high resolution for the earth's land surface areas, Scientific Data, 4, 170122, https://doi.org/10.1038/sdata.2017.122, 2017 (data available at: http://www.chelsa-climate.org, last access: 17 September 2018).

Landeck, I., Eiser, C., Ludwig, I., and Thümmel, G.: Zur aktuellen Verbreitung der Europäischen Gottesanbeterin, Mantis religiosa Linnaeus, 1758 (Mantodea, Mantidae), im Land Brandenburg, Märkische Entomologische Nachrichten, 15, 227-248, 2013.

Liana, A.: Distribution of Mantis religiosa (L.) and its changes in Poland, Fragmenta Faunistica, 50, 91-125, https://doi.org/10.3161/00159301FF2007.50.2.091, 2007.

Linn, C. A.: Ausbreitung und Etablierung Der Europäischen Gottesanbeterin "Mantis Religiosa" in Deutschland Unter Dem Einfluss Des Klima-und Landschaftswandels, Universitätsbibliothek Mainz, 2016.

Linn, C. A. and Griebeler, E. M.: Reconstruction of two colonisation pathways of Mantis religiosa (Mantodea) in Germany using four mitochondrial markers, Genetica, 143, 11-20, https://doi.org/10.1007/s10709-014-9806-1, 2015.

Linn, C. A. and Griebeler, E. M.: Habitat Preference of German Mantis religiosa Populations (Mantodea: Mantidae) and Implications for Conservation, Environ. Entomol., 45, 829-840, https://doi.org/10.1093/ee/nvw056, 2016.

Menéndez, R.: How are insects responding to global warming?, Tijdschrift voor Entomologie, 150, 355-365, 2007.

Merow, C., Smith, M. J., and Silander, J. A.: A practical guide to MaxEnt for modeling species' distributions: What it does, and why inputs and settings matter, Ecography, 36, 1058-1069, https://doi.org/10.1111/j.1600-0587.2013.07872.x, 2013.

Musolin, D.: Insects in a warmer world: ecological, physiological and life-history responses of true bugs (Heteroptera) to climate change, Glob. Change Biol., 13, 1565-1585, https://doi.org/10.1111/j.1365-2486.2007.01395.x, 2007.

Pampus, M.: Einschätzungen zu möglichen und bereits nachweisbaren Auswirkungen des globalen Klimawandels auf die Biodiversität in Hessen, Im Auftrag des Hessischen Landesamtes für Umwelt und Geologie: INKLIM 2012 - Baustein II: Klimafolgen (Abschlussberichte), available at: http://www.hlug.de/ medien/luft/inklim/dokumente/endberichte/naturschutz.pdf (last access: 29 August 2020), 2004.

Parent, G. H.: Distribution et comportement de la Mante religieuse, Mantis religiosa religiosa (L.), en limite septentrionale de son aire en Europe occidentale, Relations causales avec les fluctuations climatiques récentes, Parcs Nationaux (Ardenne et Gaume), 31, 138-175, 1976.

Pecl, G. T., Araújo, M. B., Bell, J. D., Blanchard, J., Bonebrake, T. C., Chen, I.-C., Clark, T. D., Colwell, R. K., Danielsen, F., Evengård, B., Falconi, L., Ferrier, S., Frusher, S., Garcia, R. A., Griffis, R. B., Hobday, A. J., Janion-Scheepers, C., Jarzyna, M. A., Jennings, S., Lenoir, J., Linnetved, H. I., Martin, V. Y., McCormack, P. C., McDonald, J., Mitchell, N. J., Mustonen, T., Pandolfi, J. M., Pettorelli, N., Popova, E., Robinson, S. A., Scheffers, B. R., Shaw, J. D., Sorte, C. J. B., Strugnell, J. M., Sunday, J. M., Tuanmu, M.-N., Vergés, A., Villanueva, C., Wernberg, T., Wapstra, E., and Williams, S. E.: Biodiversity redistribution under climate change: Impacts on ecosystems and human well-being, Science, 355, 1389, https://doi.org/10.1126/science.aai9214, 2017.

Petrischak, H. and Ulrich, R.: Die Gottesanbeterin Mantis religiosa LINNAEUS, 1758 im Saarland (Mantodea: Mantidae), Delattinia, 229-254, 2012.

Phillips, S. J. and Dudík, M.: Modeling of species distributions with Maxent: new extensions and a comprehensive evaluation, Ecography, 31, 161-175, https://doi.org/10.1111/j.09067590.2008.5203.x, 2008.

Phillips, S. J., Dudík, M., and Schapire, R. E. (Eds.): A maximum entropy approach to species distribution modeling, ACM, 83 pp., 2004.

Phillips, S. J., Anderson, R. P., and Schapire, R. E.: Maximum entropy modeling of species geographic distributions, Ecol. Modell., 190, 231-259, https://doi.org/10.1016/j.ecolmodel.2005.03.026, 2006.

Phillips, S. J., Dudík, M., Elith, J., Graham, C. H., Lehmann, A., Leathwick, J., and Ferrier, S.: Sample selection bias and presence-only distribution models: implications for background and pseudo-absence data, Ecol. Appl., 19, 181-197, 2009.

Robinet, C. and Roques, A.: Direct impacts of recent climate warming on insect populations, Integr. Zool., 5, 132-142, https://doi.org/10.1111/j.1749-4877.2010.00196.x, 2010.

Steger, J., Geske, C., Gottwald, J., Brandl, R., Nauss, T., and Hotes, S.: Szenarien der künftigen Verbreitung des Hirschkäfers in Hessen: Welchen Einfluss hat der Klimawandel?, Natur und Landschaft Zeitschrift für Naturschutz und Landschaftspflege, 95, 111-117, https://doi.org/10.17433/3.2020.50153783.111117, 2020.

Strachan, L. A., Tarnowski-Garner, H. E., Marshall, K. E., and Sinclair, B. J.: The evolution of cold tolerance in 
Drosophila larvae, Physiol. Biochem. Zool., 84, 43-53, https://doi.org/10.1086/657147, 2011.

Telonis-Scott, M., Gane, M., DeGaris, S., Sgrò, C. M., and Hoffmann, A. A.: High resolution mapping of candidate alleles for desiccation resistance in Drosophila melanogaster under selection, Mol. Biol. Evol., 29, 13351351, https://doi.org/10.1093/molbev/msr294, 2012.

Thomas, C. D., Cameron, A., Green, R. E., Bakkenes, M., Beaumont, L. J., Collingham, Y. C., Erasmus, B. F. N., Siqueira, M. F. de, Grainger, A., Hannah, L., Hughes, L., Huntley, B., van Jaarsveld, A. S., Midgley, G. F., Miles, L., Ortega-Huerta, M. A., Peterson, A. T., Phillips, O. L., and Williams, S. E.: Extinction risk from climate change, Nature, 427, 145-148, https://doi.org/10.1038/nature02121, 2004.

Václavík, T. and Meentemeyer, R. K.: Equilibrium or not? Modelling potential distribution of invasive species in different stages of invasion, Divers. Distrib., 18, 73-83, https://doi.org/10.1111/j.1472-4642.2011.00854.x, 2012.

Walther, G.-R., Roques, A., Hulme, P. E., Sykes, M. T., Pysek, P., Kühn, I., Zobel, M., Bacher, S., Botta-Dukát, Z., Bugmann, H., Czúcz, B., Dauber, J., Hickler, T., Jarosík, V., Kenis, M., Klotz, S., Minchin, D., Moora, M., Nentwig, W., Ott, J., Panov, V. E., Reineking, B., Robinet, C., Semenchenko, V., Solarz, W., Thuiller, W., Vilà, M., Vohland, K., and Settele, J.: Alien species in a warmer world: risks and opportunities, Trends Ecol. Evol., 24, 686-693, https://doi.org/10.1016/j.tree.2009.06.008, 2009.
Warren, D. L., Wright, A. N., Seifert, S. N., and Shaffer, H. B.: Incorporating model complexity and spatial sampling bias into ecological niche models of climate change risks faced by $90 \mathrm{Cal}-$ ifornia vertebrate species of concern, Divers. Distrib., 20, 334 343, https://doi.org/10.1111/ddi.12160, 2014.

Xu, L., Myneni, R. B., Chapin III, F. S., Callaghan, T. V., Pinzon, J. E., Tucker, C. J., Zhu, Z., Bi, J., Ciais, P., Tømmervik, H., Euskirchen, E. S., Forbes, B. C., Piao, S. L., Anderson, B. T., Ganguly, S., Nemani, R. R., Goetz, S. J., Beck, P. S. A., Bunn, A. G., Cao, C., and Stroeve, J. C.: Temperature and vegetation seasonality diminishment over northern lands, Nat. Clim. Change, 3, 581-586, https://doi.org/10.1038/nclimate1836, 2013.

Yang, X.-Q., Kushwaha, S. P. S., Saran, S., Xu, J., and Roy, P. S.: Maxent modeling for predicting the potential distribution of medicinal plant, Justicia adhatoda L. in Lesser Himalayan foothills, Ecol. Eng., 51, 83-87, https://doi.org/10.1016/j.ecoleng.2012.12.004, 2013.

Zeuss, D., Brunzel, S., and Brandl, R.: Environmental drivers of voltinism and body size in insect assemblages across Europe, Global Ecol. Biogeogr., 26, 154-165, https://doi.org/10.1111/geb.12525, 2017.

Zielinski, D., Schwarz, C. J., and Ehrmann, R.: Evaluation of the expansion of Mantis religiosa (L.) in Poland based on a questionnaire survey, Anim. Biodiv. Conserv., 41, 275-280, 2018. 